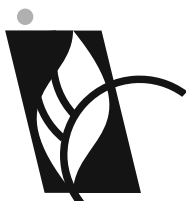

J O U R N A L

$\mathrm{O} F \bullet \mathrm{B} \mathrm{A} \mathrm{L} \mathrm{T} \mathrm{I} \mathrm{C}$

$S$ C I E N C E

E DUCATION

ISSN 1648-3898

Abstract. Alternative conceptions of 'physical and chemical change' concepts to minimize their effects on further

learning should be handled at lower secondary school in that these concepts are formally introduced at grade 6 . This study aimed to investigate the effect of storylines embedded within context-based learning approach on grade 6 students' understanding of 'physical and chemical change' concepts. To probe the students'

conceptions, Chemical and Physical Change Concept Questionnaire (CPCCQ) was employed as pre- and post-test. The results indicated that most of the students tended to pay more attention to 'reversibility' criterion in distinguishing 'chemical change' concept from 'physical change' one. Finally, it can be deduced that the storylines embedded within the contextbased learning approach not only resulted in a better meaningful learning but also increased student achievement level. To give an opportunity for the students to grasp the relevance of chemistry/science to their lives, the meaning of each daily life concept should be bridged with that in a chemistry context.

Key words: alternative conception, context-based learning approach, chemical change, physical change, science education, storylines.

Hülya Demircioğlu, Mustafa Dinç,

Muammer Çalik Karadeniz Technical University, Trabzon, Turkey
THE EFFECT DF STIRYLINES EMBEDDED WITHIN CDNTEXT-BASED

LEARNING APPRDACH IN GRADE 6 STUDENTS, UNDERSTANDING 'PHYSICAL AND CHEMICAL CHANGE' CINCEPTS

\section{Hülya Demircioğlu, Mustafa Dinç, Muammer Çalik}

\section{Introduction}

Because students are introduced with some abstract concepts in early ages, they find such concepts difficult to learn and visualize (i.e. Çalık, Kolomuç \& Karagölge, 2010; Gökdere \& Çalık, 2010). For example, in Turkish context, the students formally learn particulate nature of matter, chemical change and physical change at grade 6 (aged 11 and 12 years). This means that such concepts require the students to possess abstract reasoning competency. If not, the students may construct various alternative conceptions, which are different from the scientifically accepted one (e.g. Bakırcı \& Çalık, 2013; Ben-Zvi, Eylon \& Silberstein, 1987; Johnson, 2000). For example, a few studies report that students at different grades have difficulty in understanding 'physical and chemical change' concepts (Ayas \& Demirbaş, 1997; Çalık \& Ayas, 2005a; Gabel, 1996; Johnstone, 1991; Johnson, 2002; Robinson, 2003; Stavridou \& Solomonidou, 1989; Tsaparlis, 1997). In fact,'physical and chemical change' concepts play a significant role in making sense of further chemical phenomena, i.e. equilibrium, redox, radioactivity, chemical reactions. For this reason, an intervention study that facilitates lower-secondary students' conceptions of these concepts can be seen as a cornerstone for further learning.

\section{Theoretical Framework}

Because school science fails to get most students to sustain curiosity of the real world, science educators have attempted to find alternative ways. Of these alternative ways, the contextbased learning approach links theoretical knowledge (school 
science) with daily (real) life. Thereby, it yields a 'need to know' basis and increases their enthusiasm towards science (e.g. Pilot \& Bulte, 2006; Ültay \& Çalık, 2012). For this reason, several context-based learning approaches have been developed in various countries: e.g. Salters Advanced Chemistry in the UK (Barker \& Millar, 2000; Bennett \& Lubben, 2006), Chemistry in Context in the USA (Schwartz, 2006), Industrial Chemistry in Israel (Hofstein \& Kesner, 2006), Chemie im Kontext in Germany (Parchmann, Gräsel, Baer, Nentwig, Demuth, Ralle \& the Chik Project Group, 2006), Context-concept Approach in the Netherlands (Bulte, Westbroek, de Jong \& Pilot, 2006). Of these context-based learning approaches, The Salters Advanced Chemistryinvolves "Storyline", "Chemical ideas" and "Activities" (Barker \& Millar, 1999, 2000; Hughes, 2000; Pilling, Holman \& Waddington, 2001; Demircioğlu, Demircioğlu \& Ayas, 2006b; Demircioğlu, Demircioğlu \& Çalık, 2009; Bennett \& Lubben, 2006). However, the storylines to create the 'need to know' basis could be viewed as the "backbone" of the Salters Advanced Chemistry (Bennett \& Lubben, 2006). By doing this, the Salters Advanced Chemistry gives an opportunity for the student to analyze some phenomena that they encountered in daily life and to perceive how science is relevant with daily life (as a context) (TPSI, 1991). Also, finding pathways through known and unknown territories of knowledge, the storylines improve student cognitive processing and narrative structures (Barry, Berry, Cunningham, Newton, Schweppe, Spalter, Whiteley \& Williams, 2006). Further, the storylines enhance the students' enthusiasm towards science and their understanding of science concepts in that they are effective in such targeted features as communicating ideas, making ideas meaningful, increasing student engagement, generating a dynamic-organic "game"for learning, and enriching the learning environment with contradictory voices (Banister \& Ryan, 2001; Barry et. al., 2006; Millar \& Osborne, 1998). Given these advantages of the storylines, the authors employed the storylines in the current study.

\section{Overview of 'Physical and Chemical Change' Concepts}

Relevant literature indicates a number of alternative conceptions of 'physical and chemical change' concepts. These are: (1) a chemical reaction occurs during phase change (Ahtee $\&$ Varjola, 1998; BouJaoude, 1992; Novak \& Musonda, 1991; Stavridou \& Solomonidou, 1998), (2) a chemical reaction happens when a substance dissolves (Abraham, Williamson \& Westbrook, 1994; Ahtee \& Varjola, 1998; BouJaoude, 1992; Eilks, Moellering \& Valanides, 2007; Novak \& Musonda, 1991; Stavridou \& Solomonidou, 1998; Valanides, 2000), (3) a chemical change is always irreversible (Cavallo, McNeely \& Marek, 2003; Çalık \& Ayas, 2005a), (4) any change at sub-microscopic level is the same as that at macroscopic one (Andersson, 1990; Lee, Eichinger, Anderson, Berkheimer \& Blaskeslee, 1993), (5) a chemical reaction always require two reactants (Cavallo et al., 2003; Eilks et al., 2007), (6) a chemical reaction transforms reactants' particles into different ones (Andersson, 1986), (7) total amount of the matter is not conserved during phase change (Lee et al., 1993; Stavy, 1990), (8) total mass is not conserved in a chemical change in which gases give off (Hesse \& Anderson, 1992; Özmen \& Ayas, 2003), (9) a chemical reaction make atoms disappear (Andersson, 1986; Mitchell \& Gunstone, 1984). Furthermore, these alternative conceptions have been elicited at varied samples: grade 6 students (Mitchell \& Gunstone, 1984), grade 7 students (Ahtee \& Varjola, 1998; Eilks, Moellering \& Valanides, 2007), grade 8 students (Ahtee \&Varjola, 1998; Çalık \& Ayas, 2005a), grade 9 students (Cavallo, McNeely \& Marek, 2003), grade 10 students (Özmen \& Ayas, 2003), grade 1 to grade 12 students (Novak \& Musonda, 1991), high school students (BouJaoude, 1992; Hesse \& Andersson, 1992), student teachers (Valanides, 2000; Çalık \& Ayas, 2005a), 9-15 year-old students (Stavy, 1990), 12 to 18 year-old students (Stavridou \& Solomonidou, 1998), and 12-16 year old students (Andersson, 1990). Taking the samples in the aforementioned studies into account, it can be inferred that an increase in educational level (grade) does not remedy the alternative conceptions. For this reason, the alternative conceptions of the 'physical and chemical change' concepts to minimize their effects on further learning should be handled at lower secondary school in that these concepts are formally introduced at grade 6 . Overall, the foregoing studies call for a need to facilitate the grade 6 students' conceptual understanding and to overcome their alternative conceptions. By doing this, the authors hypothesize to eliminate conventional instruction driven alternative conceptions. 


\section{The Aim of the Study}

The aim of this study was to investigate the effect of the storylines embedded within context-based learning approach on grade 6 students' alternative conceptions of the 'physical and chemical change' concepts. Within this aim, the following research question is specifically explored: Do the storylines embedded within the context-based learning approach cause a statistically significant change in students' understanding of the 'physical and chemical change' concepts?

\section{Methodology of Research}

The present study followed a pre-experimental research design (one group pre-test/post-test design) (Ohlund \& Yu, 2009). That is, the experimental group in the present study did not have a comparison (control) group. This issue may be seen as a pitfall of the study. Indeed, Trochim (2001) views such a research design as validity threat in that its lack of random assignments and control group, limits confidence in assigning causality to an intervention. But he also discusses such design is worthwhile in particular circumstances, i.e. use of complex intervention. For the present study, the main validity threat is viewed as being involved in 'a teaching intervention' which may of itself result in an apparent improvement in conceptual understanding (e.g. Trochim, 2001; Çalık, Ayas \& Coll, 2010; Çalık, 2013). However, the inclusion of a pretest within the pre-experimental design to determine baseline scores may reduce this validity threat (Heffner, 2004). Also, using the underlying science content of the 'physical and chemical change' concepts (instead of directly aligning with the curriculum) in Chemical and Physical Change Concept Questionnaire (CPCCQ) indicates effect of independent variable (the storylines embedded within the context-based learning approach) on dependent variable (student understanding) and decreases the pre-experimental research design's validity threat (Sadler, 2009).

\section{Sample of Research}

This study was conducted with 35 (18 girls and 17 boys) grade 6 students in a primary school in the city of Trabzon, Turkey.

\section{Instrument and Procedures}

To decide the CPCCQ's content, the authors examined grade 6 science and technology curriculum and studies of 'physical and chemical change' concepts (e.g. Cavallo, McNeely \& Marek, 2003; Çalık \& Ayas, 2005a; Stavridou \& Solomonidou, 1989). Then, they devised Chemical and Physical Change Concept Questionnaire (CPCCQ) with ten multiple-choice items (5 items for discriminating physical change from chemical change--, 5 items for identifying change(s) in inner or outer structure (composition) of the matter in physical and chemical change) Also, a group of experts, i.e. three chemistry educators and two science teachers went over the questionnaire and confirmed its content validity. In addition, the questionnaire was pilot-tested with forty grade 7 students who had already attended the concepts under investigation. Its Cronbach alpha reliability coefficient was found to be 0.82 which is quite higher than the acceptable value (0.70) suggested by Hair, Black, Babin, Anderson, \& Tatham (2006). Two of items in the CPCCQ is displayed in the following:

Item 3: Which of the following is a chemical change example?
a) melting of ice
b) corrosion of zinc*
c) telephone wires sag
d) dissolving of salt into water

Item 4: Which of the following does not change with an increase in temperature of oxygen gas in an elastic balloon? 


\author{
e) Volume \\ f) Distance between particles \\ g) Mass* \\ h) Physical properties
}

The CPCCQ was administered as a pre-test two weeks before the teaching intervention and readministered as a post-test two weeks after the teaching intervention. This was deliberate in that the authors planned to allow at least some time distance from the intervention as a means of addressing a Hawthorne type effect (e.g. Çalık, Ayas \& Coll, 2007, 2009; Guba \& Lincoln, 1994). This time gap means that straight memory recall should be less influential in improved performance.

\title{
Teaching Intervention
}

To develop the context-based learning material (CBLM), the authors examined a number of related resources, such as grade 6 science textbooks, publications of Salters Advanced Chemistry, and grade 6 science and technology curriculum. Given the student active engagement within the context based approach, a two-class hour- teaching intervention (2x45 minutes) was designed. A group of experts, three experienced chemistry teachers (6 to 15-year teaching background) and three chemistry educators (who held PhD in chemistry education), looked over and ensured the content of the CBLM. An outline of the teaching design is represented in Table 1.

Table 1. An outline of the teaching design.

\begin{tabular}{|c|c|c|}
\hline $\begin{array}{c}\text { Lesson } \\
\text { Plan }\end{array}$ & Teacher's role & Student's role \\
\hline 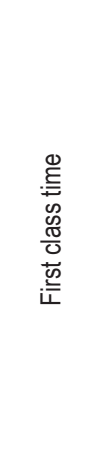 & $\begin{array}{l}\text { - Teacher began the course with 'The Changes in Our Life' storyline } \\
\text { (Appendix 1). Then, she asked the following questions to stimulate } \\
\text { their notions through class-discussion: "What do you think about } \\
\text { the story? What changes happened in this storyline? What do you } \\
\text { think about type of change (physical or chemical change)? Please } \\
\text { defend your reason" } \\
\text { - After reading the storyline, she asked the students to find the key } \\
\text { concepts/events about physical and chemical changes. } \\
\text { - She required the students to perform Activity 'Is it a physical or } \\
\text { chemical Change?' (Appendix 2) in their small groups of 5-6 } \\
\text { students. } \\
\text { She encouraged them to share their views with peers through the } \\
\text { class-discussion. }\end{array}$ & $\begin{array}{l}\text { - They found and discussed the related } \\
\text { key concepts by carefully reading the } \\
\text { storyline. } \\
\text { - They performed the Activity "Is it a physical } \\
\text { or chemical change?" in their small groups } \\
\text { of 5-6 students. }\end{array}$ \\
\hline 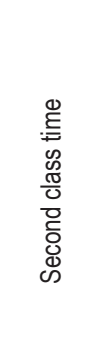 & $\begin{array}{l}\text { - She discussed the 'physical and chemical change' concepts via } \\
\text { power-point presentation. } \\
\text { - She fostered the students to link their results with the scientific ones } \\
\text { by asking some related questions. } \\
\text { - } \quad \text { She called the students to create their own data tables and to } \\
\text { presentto the entire class. } \\
\text { - She summarized properties of physical and chemical change and } \\
\text { presented relevant daily-life pictures and molecular-level images. }\end{array}$ & $\begin{array}{l}\text { - In their small groups, they responded the } \\
\text { - } \quad \text { Suestion prompted by the teacher. } \\
\text { results to the entire class. } \\
\text { - Each group created their data tables of } \\
\text { the properties of physical and chemical } \\
\text { change and presented them to the entire } \\
\text { class. } \\
\text { They participated in the class-discussion } \\
\text { moderated by the teacher. }\end{array}$ \\
\hline
\end{tabular}

\section{Data Analysis}

In analyzing the CPCCQ data, maximum score was 50 points (5 points for each correct response and zero point for incorrect one). The results of the pre- and post-test's scores were compared using paired-samples t test 
CHANGE' CONCEPTS

(P. $682-691$ )

\section{Results of Research}

Table 2 indicates frequencies and percentages of the grade 6 students' responses to the CPCCQ for the pre-test and the post-test.

Table 2. Frequencies and percentages of the grade 6 students' responses to the CPCCQ for the pre-test and the post-test.

\begin{tabular}{|c|c|c|c|c|c|c|c|c|c|}
\hline \multirow{3}{*}{ Principal Theme } & \multirow{3}{*}{$\begin{array}{l}\text { Item } \\
\text { Number }\end{array}$} & \multicolumn{4}{|c|}{ Incorrect Choices } & \multicolumn{4}{|c|}{ Correct Choices } \\
\hline & & \multicolumn{2}{|c|}{ Pre-test } & \multicolumn{2}{|c|}{ Post-test } & \multicolumn{2}{|c|}{ Pre-test } & \multicolumn{2}{|c|}{ Post-test } \\
\hline & & $f$ & $\%$ & $f$ & $\%$ & $f$ & $\%$ & $f$ & $\%$ \\
\hline \multirow{5}{*}{$\begin{array}{l}\text { Discriminating physical change from chemical } \\
\text { change }\end{array}$} & 3 & 8 & 23 & 2 & 6 & 27 & 77 & 33 & 94 \\
\hline & 5 & 22 & 63 & 5 & 14 & 13 & 37 & 30 & 86 \\
\hline & 8 & 8 & 23 & 1 & 3 & 27 & 77 & 34 & 97 \\
\hline & 9 & 9 & 26 & - & - & 26 & 74 & 35 & 100 \\
\hline & 6 & 11 & 31 & 1 & 3 & 24 & 69 & 34 & 97 \\
\hline \multirow{5}{*}{$\begin{array}{l}\text { Identifying change(s) in inner or outer structure } \\
\text { (composition) of the matter in physical and } \\
\text { chemical change }\end{array}$} & 2 & 15 & 43 & 4 & 11 & 20 & 57 & 31 & 89 \\
\hline & 4 & 28 & 80 & 3 & 9 & 7 & 20 & 32 & 91 \\
\hline & 7 & 17 & 49 & 6 & 17 & 18 & 51 & 29 & 83 \\
\hline & 1 & 32 & 91 & 2 & 6 & 3 & 9 & 33 & 94 \\
\hline & 10 & 12 & 34 & 3 & 9 & 23 & 66 & 32 & 91 \\
\hline
\end{tabular}

As can be seen in Table 2, percentages of the students who gave correct responses in the pre-test were between $9 \%$ and $77 \%$, whereas those in the post-test were between $83 \%$ and $100 \%$. Further, as seen in Table 3, the results of the paired samples $t$ test showed a significant difference between the pre- and post-test mean scores in favor of the post-test scores $(t=13.943, p<0.05)$.

Table 3. The results of the paired samples $t$-test on the pre- and post-test mean scores of the CPCCQ.

\begin{tabular}{cccccccc}
\hline Tests & $\mathbf{N}$ & Mean & SD & Mean difference & $\mathbf{t}$ & df & Sig. (2-tailed) \\
\hline Pretest & 35 & 32.00 & 6.09 & 14.14 & 13.943 & 34 & 0.000 \\
Posttest & 35 & 46.14 & 3.45 & & & \\
\hline
\end{tabular}

The grade 6 students' responses to the CPCCQ for the pre-test and the post-test were also analyzed to portray the extent to which conceptual change attained (see Table 4).

Table 4. Percentages of the students' alternative conceptions in the pre-test and the post-test.

\begin{tabular}{lccc}
\hline \multicolumn{1}{c}{ Alternative conceptions } & PrT & PoT & CC \\
\hline $\begin{array}{l}\text { A chemical change only modifies inner structure (composition) of the matter but } \\
\text { not change outer structure (composition) of the matter }\end{array}$ & 70 & - & +70 \\
A chemical change is always irreversible & 9 & 94 & -85 \\
Any heating process results only in the physical change & 63 & 14 & +49 \\
A chemical change does not change chemical composition of the matter & 34 & 9 & +25
\end{tabular}




\begin{tabular}{lcccc}
\hline \multicolumn{1}{c}{ Alternative conceptions } & PrT & PoT & CC & $R$ \\
\hline Phase change of ice into water is a chemical change & 23 & 3 & +20 & $\mathrm{R}$ \\
Dissolving process is always a physical change & 91 & 6 & +85 & $\mathrm{R}$ \\
Rusting process is a physical change example & 60 & 9 & +51 & $\mathrm{R}$ \\
Phase change of matter increases or decreases sizes of particles & 80 & 9 & +71 & $\mathrm{R}$ \\
Phase change of matter yields a new (different) matter & 49 & 17 & +28 & $\mathrm{R}$ \\
\hline
\end{tabular}

PrT: Pre-test, PoT: Post-test, CC: Conceptual change, R: Retention; NR: Not retain; +, positive conceptual change; -, negative conceptual change

\section{Discussion}

As seen in Table 4, a significant proportion of the grade 6 students' alternative conceptions was replaced with the scientific ones. This means that the storylines embedded within the context-based learning approach were effective in remedying their alternative conceptions and achieving conceptual change (Ayvacı \& Çoruhlu, 2009; Banister \& Ryan, 2001; Demircioğlu et al., 2009; Demircioğlu, 2012). In fact, a conceptual improvement is always an expected issue after any teaching intervention. For the current teaching intervention, given a 'need to know' basis linking theoretical knowledge with practical one seems to have improved their meaningful learning abilities (Banks, 1997; Bennett, 2005; Demircioğlu et al., 2009; Tsai, 2000; Ültay \& Çalık, 2012; Winther \& Volk, 1994; Yager \& Weld, 1999). Moreover, the authors informally observed the grade 6 students' interest to find the key concepts in the storylines and to share their gained experiences with peers through their small groups and class discussion. Such an effect may stem from the nature of the context-based learning approach that stimulates their interests towards science (Bennett, Lubben, \& Hogarth, 2003; Ültay \& Çalık, 2012). This reveals that the grade 6 students much more willing to engage with the context-based chemistry materials. This is in a harmony with Sutman and Bruce's (1992) claim that North-American high school students were much more willing to engage with context-based chemistry materials than traditional materials.

Unfortunately the context-based learning approach seems to have fully only one out of the nine alternative conceptions (see Table 4). This arises a new hypothesis 'all alternative conceptions cannot be fully diminished with only one learning approach'. In fact, even though some authors assumed that using a combination of conceptual change methods would fully eliminate all alternative conceptions probed by their samples, they reported that the hypothesis seems to have run only for some alternative conceptions (i.e. Çalık, Ayas \& Coll, 2010; Çalık, Okur \& Taylor, 2011; Çoruhlu-Şenel, Çalık \& Çepni, 2012; Karslı \& Çalık, 2012). This appears that hard-core alternative conceptions are resistant to change even if instruction (or intervention) is directly designed to address them (Ayas, Özmen \& Çalık, 2010; Demircioglu, 2009; Tanel, 2013; Vosniadou, loannides, Dimitrakopoulou, \& Papademetriou, 2001). In other words, this also advocates that several factors, rather than one factor, may engender to various alternative conceptions (e.g. Çalık \& Ayas, 2005a; Kolomuç \& Çalık, 2012).

An increase on the alternative conception 'A chemical change is always irreversible' may be explained with some reasons. That is, due to Piagetian term at this grade (i.e. concrete operational term), the 'physical and chemical change' concepts are taught by means of only irreversibility criterion. However, such an instruction seems to have triggered insidious alternative conceptions to some extent. In fact, our cognitive system contains competitive knowledge types, i.e. alternative conception and scientific conception (e.g. Çalık \& Ayas, 2005b; Karslı \& Çalık, 2012). Also, dominant knowledge in the cognitive system is initially retrieved from the cognitive mind (e.g. Çalık \& Ayas, 2005b). To sum up, the present teaching intervention somewhat seems to have changed this competitive environment in the cognitive system in favor of the scientific conception (see Table 4). 

CHANGE' CONCEPTS

(P. $682-691$ )

\section{Conclusions and Recommendations}

Even though pre-service education gives an opportunity for pre-service teachers to keep up with contemporary trends in science education, in-service teachers still possess little chance to catch these trends as compared their total numbers, for instance, 400,000 teachers have been employing in nearly 35,000 primary schools in Turkey. In other words, whatever approach is used to improve science education, teachers should be persuaded to its efficacy and benefits. This then indicates a need for regular and substantial in-service teacher training program (Çalık \& Ayas, 2008). Therefore, the teachers should be practically informed about the storylines and the context based learning approach. By doing this, the teachers will be able to grasp how to design (or create) a student-centered learning environment (e.g. Çalık \& Ayas, 2008; Demircioğlu et al., 2009).

Because textbooks are still seen as one of the main sources in the learning process (e.g. Erdemir \& Topçu, 2012), the textbook authors should be informed on contemporary educational trends/approaches. Hence, they may pay more attention on how to adapt these trends into the textbooks. Further, to give an opportunity for the students to grasp the relevance of chemistry/science to their lives, the meaning of each daily life concept should be bridged with that in a chemistry context (De Jong, 2008). Thereby, students' applied knowledge and skills should be paralleled to their theoretical knowledge in order for accomplishing meaningful learning. In a similar vein, they will be able to consider that science and chemistry are everywhere around them. Such an attempt may replace negative attitudes towards science/science courses with positive ones.

Appendices: Please visit the link at http://www.academia.edu/3642652/JBSE_Appendices

\section{References}

Abraham, M. R., Williamson, V. M., \& Westbrook, S. L. (1994). A cross-age study of the understanding five concepts. Journal of Research in Science Teaching, 31 (2), 147-165.

Ahtee, M., \& Varjola, I. (1998). Students' understanding of chemical reaction. International Journal of Science Education, 20 (3), 305-316.

Andersson, B. (1986). Pupils' explanations of some aspects of chemical reactions. Science Education, 70 (5), 549563.

Andersson, B. (1990). Pupils' conceptions of matter and its transformations (age 12-16). Studies in Science Education, $18,53-85$.

Ayas, A., \& Demirbaş, A. (1997). Turkish secondary students' conception of introductory chemistry concept. Journal of Chemical Education, 74 (5), 518-521.

Ayas, A., Özmen, H., \& Çalık, M. (2010). Students' conceptions of the particulate nature of matter at secondary and tertiary level. International Journal of Science and Mathematics Education, 8 (1), 165-184.

Ayvacı, H. Ş., \& Çoruhlu, T. (2009). Effects of explanatory stories on elimination of students' misconceptions about physical and chemical change. Ondokuz Mayıs University Journal of Education, 28, 93凶104.

Bakırcı, H., \& Çalık, M. (2013). Adaptasyon ve doğal seçilim konusunda geliştirilen rehber materyallerin sekizinci sınıf öğrencilerinin alternatif kavramlarının giderilmesine etkisi [Effect of guide materials developed in 'adaptation and natural selection' subject on remedying grade 8 students' alternative conceptions]. Eğitim ve Bilim [Education and Science], 38 (168), 215-229 (in Turkish).

Banister F., \& Ryan, C. (2001). Developing science concepts through story-telling. School Science Review, 83 (302), 75-83.

Banks, P. (1997). Students' understanding of chemical equilibrium. University of York, UK: Unpublished MA thesis.

Barker, V., \& Millar, R. (1999). Students' reasoning about chemical reactions: What changes occur during a contextbased post-16 chemistry course? International Journal of Science Education, 21, 645-665.

Barker, V., \& Millar, R. (2000). Students'reasoning about basic chemical thermodynamics and chemical bonding: what changes occur during a context-based post-16 chemistry course? International Journal of Science Education, $22,1171-1200$.

Barry, A., Berry, D., Cunningham S., Newton, J., Schweppe, M., Spalter, A., Whiteley, W., \& Williams, R. (2002). Visual Learning for Science and engineering. Report from the Visual Learning Campfire. Snowbird, UT. Available at http://www.siggraph.org/education/vl/vl.htm Accessed May 12, 2006.

Bennett, J. (2005). Bringing science to life: the research evidence on teaching science in context, York, UK: Department of Educational Studies, The University of York Retrieved September 4, 2007 from http://www.york.ac.uk/depts/ educ/ResearchPaperSeries /Contextsbooklet.pdf. 
Bennett, J., \& Lubben, F. (2006, July). Context-based chemistry: the Salters approach, International Journal of Science Education, 28, 999-1015.

Bennett, J., Lubben, F., \& Hogarth, S. (2003). A systematic review of the effects of context-based and Science Technology-Society (STS) approaches to the teaching of secondary science. Research Evidence in Education Library [REEL]. www.eppi.ioe.ac.uk

Ben-Zvi, R., Eylon, B. S., \& Silberstein, J. (1986). Is an atom of Copper malleable? Journal of Chemical Education, 63 (1), 64-66.

BouJaoude, S. B. (1992). The relationship between students' learning strategies and the change in their misunderstandings during a high school chemistry course. Journal of Research in Science Teaching, 29 (7), 687-699.

Bulte, A. M. W., Westbroek, H. B., de Jong, O., \& Pilot, A. (2006). A research approach to designing chemistry education using authentic practices as contexts. International Journal of Science Education, 28, 1063-1086.

Çalık, M. (2013). Effect of technology-embedded scientific inquiry on senior science student teachers'self-efficacy. Eurasia Journal of Mathematics, Science \& Technology Education, 9 (3), 223-234, DOI:10.12973/eurasia.2013.931a.

Çalık, M., \& Ayas, A. (2005a). A comparison of level of understanding of eight grade students and science student teachers related to selected chemistry concepts. Journal of Research in Science Teaching, 42 (6), 638-667.

Çalık, M., \& Ayas, A. (2005b). A cross-age study on the understanding of chemical solution and their components. International Education Journal, 6 (1), 30-41.

Çalık, M., \& Ayas, A. (2008). A critical review of the development of the Turkish science curriculum, in Science education in context: an international examination of the influence of context on science curricula development and implementation, R. K. Coll and N. Taylor, (eds.) Sense Publishers B.V., AW Rotterdam, The Netherlands, pp.161-174.

Çalık, M., Ayas, A., \& Coll, R. K. (2007). Enhancing pre-service primary teachers' conceptual understanding of solution chemistry with conceptual change text. International Journal of Science and Mathematics Education, 5 (1), $1-28$.

Çalık, M., Ayas, A., \& Coll, R. K. (2009). Investigating the effectiveness of an analogy activity in improving students' conceptual change for solution chemistry concepts. International Journal of Science and Mathematics Education, 7 (4), 651-676.

Calık, M., Ayas, A., \& Coll, R. K. (2010). Investigating the effectiveness of usage of different methods embedded with four-step constructivist teaching strategy. Journal of Science Education and Technology, 19 (1), 32-48.

Çalık, M., Kolomuç, A., \& Karagölge, Z. (2010). The effect of conceptual change pedagogy on students' conceptions of rate of reaction. Journal of Science Education and Technology, 19, 422-433.

Çalık, M., Okur, M., \& Taylor, N. (2011). A comparison of different conceptual change pedagogies employed within the topic of "sound propagation". Journal of Science Education and Technology, 20, 729-742.

Cavallo, A. M. L., McNeely, J. C., \& Marek, E. A. (2003). Eliciting students' understandings of chemical reactions using two forms of essay questions during a learning cycle. International Journal of Science Education, 25 (5), 583-603.

Champagne, A. B., Gunstone, R. F., \& Klopfer, L. E. (1983). Naive knowledge and science learning. Research in Scince \& Technological Education, 1, 173-183.

Çoruhlu-Şenel, T., Çalık, M., \& Çepni, S. (2012). Effect of conceptual change pedagogies on students' alternative conceptions of electricity resistance and electricity current. Energy, Education, Science and Technology Part B Social and Educational Studies, 4 (1), 141-152.

De Jong, O. (2008). Context-based chemical education: How to improve it? Chemical Education International, 8 (1), 1-7. Retrieved from December 11, 2009 from http://old.iupac.org/publications/cei/vol8/index.html.

Demircioğlu, H., Demircioğlu, G., \& Ayas, A. (2006b). Storylines and chemistry teaching, Hacettepe University Journal of Education, 30, 110-119.

Demircioglu, G. (2009). Comparison of the effects of conceptual change texts implemented after and before instruction on secondary school students' understanding of acid-base concepts. Asia Pacific Forum on Science Learning and Teaching, 10 (5).

Demircioğlu, H. (2012). The effects of storylines embedded within the context-based approach on grade 10 student' conceptions of the change of states. Energy Education Science and Technology Part B: Social and Educational Studies, 4 (4), 2429-2438.

Demircioğlu, H., Demircioğlu, G., \& Çalık, M. (2009). Investigating effectiveness of storylines embedded within context based approach: The case for the periodic table. Chemistry Education: Research and Practice, 10, 241-249.

Erdemir, N., \& Topcu, M. S. (2012). The impact of presentation graphics on preservice science teachers' attitudes towards physics. Journal of Baltic Science Education, 11 (2), 141-152.

Eilks, I., Moellering, J., \& Valanides, N. (2007). Seventh-grade students' understanding of chemical reactions: Reflections from an action research interview study. Eurasia Journal of Mathematics, Science \& Technology Education, $3(4), 271-286$

Gabel, D. (1996). The complexity of chemistry: Research for teaching in the 21st century. Paper presented at the 14th International Conference on Chemical Education, Brisbane, Australia.

Gökdere, M., \& Çalık, M. (2010). A cross-age study of Turkish students' mental models: An "Atom" concept. Didactica Slovenica-Pedagoska Obzorja, 25 (2), 185-199.

Guba, E. G., \& Lincoln, Y. S. (1994). Competing paradigms in qualitative research. In N.K. Denzin \& Y.S. Lincoln (Eds.) 
CHANGE' CONCEPTS

(P. $682-691$ )

Handbook of qualitative research (pp. 105-117). Thousand Oaks, California: Sage.

Hair, J. F. Jr., Black, W. C., Babin, B. J., Anderson, R. E., \& Tatham, R. L. (2006). Multivariate data analysis (6th ed.). New Jersey: Prentice-Hall International.

Heffner, C. L. (2004). Research methods. Retrived May 13, 2011 from http://allpsych.com/researchmethods/preexperimentaldesign.html.

Hesse, J. J., \& Anderson, C.W. (1992). Students' conceptions of chemical change. Journal of Research in Science Teaching, 29 (3), 277-299.

Hofstein, A., \& Kesner, M., (2006), Industrial chemistry and school chemistry: Making chemistry studies more relevant. International Journal of Science Education, 28, 1017-1039.

Hughes, G. (2000). Marginalization of socioscientific material in science-technology-society science curricula: some implications for gender inclusivity and curriculum reform. Journal of Research in Science Teaching, 37, 426-440.

Johnson, P. (2000).developing students' understanding of chemical change: What should we be teaching? Chemistry Education: Research and Practice in Europe, 1 (1), 77-90.

Johnson, P. (2002). Children's understanding of substances, Part 2: Explaining chemical change. International Journal of Science Education, 24 (10), 1037-1054.

Johnstone, A. H. (1991). Why science is is difficult to learn? Things are seldom what they seem. Journal of Computer Assisted Learning, 7, 75-83.

Karslı, F., \& Çalık, M. (2012). Can freshman science student teachers' alternative conceptions of 'electrochemical cells' be fully diminished? Asian Journal of Chemistry, 24 (2), 485-491.

Kolomuç, A. \& Çalık, M. (2012). A comparison of chemistry teachers' and grade 11 students' alternative conceptions of 'rate of reaction'. Journal of Baltic Science Education, 11 (4), 333-34.

Lee, O., Eichinger, D. C., Anderson, C. W., Berkheimer, G. D., \& Blaskeslee, T. D. (1993). Changing middle school students' conceptions of matter and molecules. Journal of Research in Science Teaching, 30 (3), 249-270.

Millar, R., \& Osborne J. (eds.) (1998). Beyond 2000. Science education for the future. London: School of Education, King's College London.

Mitchell, I., \& Gunstone, R. (1984). Some student conceptions brought to the study of stoichiometry. Research in Science Education, 14, 78-88.

Novak, J. D., \& Musonda, D. (1991). A twelve-year longitudinal study of science concept learning. American Educational Research Journal, 28 (1), 117-153.

Ohlund, B., \&Yu, C. (2009). Threats to validity of research design, Received March 09, 2010 from http://www.creativewisdom.com/teaching/WBI/threat.shtml.

Özmen, H., \& Ayas, A. (2003). Students' difficulties in understanding of the conservation of matter in open and closedsystem chemical reactions. Chemistry Education: Research and Practice, 4, 279-290.

Parchmann, I., Gräsel, C., Baer, A., Nentwig, P., Demuth, R., Ralle, B., \& the Chik Project Group (2006). “Chemie im Kontext": A symbiotic implementation of a context-based teaching and learning approach. International Journal of Science Education, 28, 1041-1062.

Pilling, G., Holman J., \& Waddington, D. (2001). The Salters' experience. Education in Chemistry, 38, 131-136.

Pilot, A., \& Bulte, A. M. W. (2006). Why do you "need to know"? Context-based education. International Journal of Science Education, 28 (9), 953-956.

Robinson, W. (2003). Chemistry problem-solving: Symbol, macro, micro and process aspects. Journal of Chemical Education, 80, 978-982.

Sadler, T.D. (2009). Situated learning in science education: Socio-scientific issues as contexts for practice. Studies in Science Education, 45 (1), 1-42.

Schwartz, A. T. (2006). Contextualised chemistry education: the American experience. International Journal of Science Education, 28, 977-998.

Solomonidou, C., \& Stavridou, E. (2000). From inert object to chemical substance: Students' initial conceptions and conceptual development during an introductory experimental chemistry sequence. Science Education, 84 (3), 382-400.

Stavridou, H., \& Solomonidou, C. (1998). Conceptual reorganization and the construction of the chemical reaction concept during secondary education. International Journal of Science Education, 20 (2), 205-221.

Stavridou, H., \& Solomonidou, C. (1989). Physical phenomena- chemical phenomena: Do pupils make the distinction? International Journal of Science Education, 11(1), 83-92.

Stavy, R. (1990). Children's conceptions of changes in the state of matter: From liquid (or solid) to gas. Journal of Research in Science Teaching, 27 (3), 247-266.

Sutman, F., \& Bruce, M. (1992). Chemistry in the community - Chemcom. Journal of Chemical Education, 69, 564567.

Tanel, R. (2013). Prospective physics teachers' self-efficacy beliefs about teaching and conceptual understandings for the subjects of force and motion. Journal of Baltic Science Education, 12 (1), 6-20

The Physical Sciences Initiative (TPSI), (1991). Social and applied aspects; what is meant by "social and applied"? www. psi-net.org/chemistry/s1/socialandapplied.pdf. 
Trochim, W. M. K. (2001). The research methods knowledge base. Atomic Dog, Cincinnati.

Tsai, C. C. (2000). The effects of STS oriented instructions on female tenth graders' cognitive structure outcomes and the role of student scientific epistemological beliefs. International Journal of Science Education, 22, 1099-1115.

Tsaparlis, G. (1997). Atomic and molecular structure in chemical education: A critical analysis from various perspectives of science education. Journal of Chemical Education, 74, 922-925.

Ültay, N., \& Çalık, M. (2012). A thematic review of studies into the effectiveness of context-based chemistry curricula. Journal of Science Education and Technology, 21 (6), 686-701.

Valanides, N. (2000). Primary student teachers' understanding of the particulate nature of matter and GTS transformations during dissolving. Chemistry Education: Research and Practice, 1 (2), 249-262.

Vosniadou, S., loannides, C., Dimitrakopoulou, A., \& Papademetriou, E. (2001). Designing learning environments to promote conceptual change in science. Learning and Instruction, 11, 81-419.

Winther, A. A., \& Volk, T. L. (1994). Comparing achievement of inner-city high school students in traditional versus STS-based chemistry courses. Journal of Chemical Education, 71, 501-505.

Yager, R. E., \& Weld, J. D. (1999). Scope, sequence and co-ordination: the lowa project, a national reform effort in the USA. International Journal of Science Education, 21, 169- 194.

Received: April 27, 2013

Accepted: September 15, 2013

Hülya Demircioğlu

Mustafa Dinç

Muammer Çalık
PhD, Assistant Professor of Chemistry Education, Karadeniz Technical University, Fatih Faculty of Education, Department of Secondary Science and Mathematics Education, Trabzon, Turkey. E-mail: hulyadem76@hotmail.com

PhD Candidate, Karadeniz Technical University, Graduate School of Educational Sciences, Department of Chemistry Education, Trabzon, Turkey.

$\mathrm{PhD}$, Associate Professor of Chemistry Education, Karadeniz Technical University, Fatih Faculty of Education, Department of Primary Teacher Education, Trabzon, Turkey.

E-mail: muammer38@hotmail.com Website: http://ktu.academia.edu/MUAMMERCALIK 